\title{
Education for Environmental Sustainability: A Green School Development
}

\author{
Adi Suryani $^{1}$, Soedarso ${ }^{2}$, Moh. Saifulloh ${ }^{3}$, Zainul Muhibbin ${ }^{4}$, \\ Wahyuddin $^{5}$, Tony Hanoraga ${ }^{6}$, Muchammad Nurif ${ }^{7}$, Umi Trisyanti ${ }^{8}$, \\ Lienggar Rahadiantino ${ }^{9}$, Deti Rahmawati ${ }^{10}$
}

\begin{abstract}
Natural environment should be cared and sustained. It is a place for human to live and develop their social and economical world. Moreover, it is also a site for many biodiversity to live together in a balanced ecosystem. Recently, global awareness is directed to the alarming destruction of environment and its' potential threats for human and other living things, as the impacts of human social-economical activities. Many efforts are executed to avoid or minimize future environmental damage. One of those endeavours is environmental education for young generation. Growing children's environmental knowledge, protection skills and management as well as caring and responsible character can be an endurant solution. This study aims to examine some learning aspects in environmental education through green school development in MI Walisongo, Desa Sawohan, Sidoarjo. The study is based on a qualitative inquiry conducted by using direct participant observation as its' data collection method. The study finds that environmental education requires a wide range of learning experiences, relating to emotion, direct practice and cognition development. In Green School MI Walisongo Desa Sawohan, those experiences are manifested into several learning processes: participative learning, modeling, character building, green site building, learning through game and peer team working.
\end{abstract}

Keywords - environmental education, environmental sustainability, green school

\section{INTRODUCTION}

Education is the backbone of development. Education prepares human resources for being active development participants. Moreover, it provides quality human capital asset through knowledge, skills and affective capacity building. Thus, education is a development pathway, which prepares path and infrastructure for development initiative and sustainability.

Currently, the rapid technology and science development facilitates and ease human livelihood. It also tremendously impacts on people's increased economy,

\footnotetext{
${ }^{1-10}$ Adi Suryani, Soedarso, Moh, Saifulloh, Zainul Muhibbin, Wahyuddin, Tony Hanoraga, Muhammad Nurif, Umi Trisyanti, Lienggar Rahadiantino, Deti Rahmawati, Department of Development Studies, ITS (Institut Teknologi Sepuluh Nopember), Surabaya, 60119.

E-mail:11adisuryani.rahman@gmail.com, 22soedarsoits.@gmail.com, ${ }^{3}$ saifultauchid@gmail.com, ${ }^{4}$ muhibbin@mku.its.ac.id,

${ }^{5}$ wahyuddin@mku.its.ac.id, ${ }^{6}$ hanoraga89@yahoo.co.id,

7nurif@mku.its.ac.id, ${ }^{8}$ umi@its.ac.id, ${ }^{9}$ lienngardian@gmail.com,

${ }^{10}$ dettyrahma55@gmail.com
}

lifestyle changing, and human satisfaction. However, frequently these changes deteriorates environment quality, even gradually destroy our natural ecosystem. Greenhouse effects, forest burning or fire, fossil fuel excessive emission as well as human activities sacrificing natural environment, such as road building, human housing, even more human hobbies and enjoyment, are several of wide range impetus of natural environment destruction. Even more, this natural destruction may worsen climate changes which threaten the life vulnerability of other species, including animals and vegetations. The threatened life of polar bears, snow leopards or Asian elephants because of the changing climate can be initial indicators of natural potential disasters. The alarming risk of certain animal extinction can be natural warning for human to seriously start caring and protecting natural environment sustainability.

There are numerous measures taken to protect and sustain natural environment. Wildlife protection programs, conservation technology and science development, natural environment protection policy, renewable and alternative energy exploration, natural environment remedies as well as global awareness campaign are several actions done to prevent natural catastrophe. Global awareness is arised at various levels: international, national as well as at the individual and society spheres.

Environmental care actions should be immediately taken since the environment destruction means the decreasing quality of human life in the context of humannatural environment ecological dependency. However, there is no single effective solution can be taken to decipher environmental sustainability issues and save the planet. Mitigation, recovery or technology development is not sufficient to respond the environmental challenge nowadays. Instead, combined actions are needed. One of the intertwined possible is environmental education. Education is the stimulant of human changes. It is expected that through environmental education, people are aware of the basic needs in harmonious human-nature relationship and create global healthy environment.

This study aims to examine children environmental education in a rural school. It is focused on strategy development and learning process to educate children (elementary students at 4th and 5th years/levels). The educational intervening program is designed to prepare the young generation by growing their care, awareness 
and sensitivity on their school and surrounding environment. The environmental sustainability care and protection need continual process [1, p. 2121]. Thus, preparing the young generation may reduce the future potential natural damage as well as sustain the environment.

\section{A. Environmental: Sustainability and Alarming Damage}

Environment is inseparable from human live. Environment is defined as any physical, chemical as well as biological aspects external to human and affects human behavior [2, p. 22]. Similarly, Young [3, p. 3] explains environment as natural and physical world determining human's living aspects. This indicates the human's independency on their environment. The human ecologists believe that natural environment and society are interrelated and human should be nature caretakers as well as understand the impacts of natural preservation and deterioration on human livelihood [4, p. 3913]. Thus, environmental sustainability is determined by human behavior towards nature [5, p. 1].

Currently, global concern is directed to environmental issue since many environmental damages as the consequences of human activities are emerging. Environment is one of the alarming issues in 21 st century since all nations need to get adequate natural resources in good quality, balanced ecosystem and maintained plant and animal biodiversity [5, p. 1]. The severity and sources of environmental damages are researched and assessed by environmentalists and environment scholars. Population growth, affluence, technology, industrialized institutions, industrial culture are some drivers of environmental damage [5, pp. 6-10]. Other causes of environmental destruction are massive natural resources consumption and accelerated economic growth [6, p. 4998], demographic dynamic, uncontrolled economic development, fossil-fuel high dependency, socio-political decision making and inequality reduction to giant power disparity [7, pp. 7-11], natural resource depletion, mining, mining process [1], population explosion and its' associated impacts (urbanization, increased carbon dioxide and greenhouse effect) [8]. Some catastrophic impacts of human attitude towards nature are also studied. Climate changes manifested in temperature rising, drought, desertification, increased precipitation, rising sea level, flood, unpredictable weather are some instances of environmental challenges [9, p. 3]. The increased sea levels as caused by global warming affected by the increased carbon dioxide can also threaten human and other species [7, p. 12]. The decreased quality of natural environment impacts on central human live aspects, including food security, water security and human security [7, pp. 19-21].

The alarming risks of environmental damage call global concern. Environment is central for human lives, since it sustain human live through its ecosystem and natural resources for livelihood [10, p. 22]. Thus, various measures need to be taken. Practicing green living by using green products is an way to reduce environmental damage [6]. The other act is environmental remedies through environmental impact assessment framework embodying detail practical guidelines, monitoring, damage evaluation and report to allow the exploiting companies execute mandatory precaution, treatment and compensation [1, p. 2121]. Implementing green economic development and proper REDD+ (Reducing Emissions from Deforestation and forest Degradation) are some instances to prevent the biodiversity loss [7, pp. 18-19]. Differently, the environmental philosophers focus on arising people awareness, responsible and moral conduct on environment [11]. The other approach is training leaders and role models to implement FSSD (A Framework for Strategic Sustainable Development) [7, pp. 20-21]. The introduction to the environmental education in any forms, ranging from formal to less formal learning for children as one of the millennium development goals, shows the contribution of education in protecting natural environment [9].

\section{B. Environmental Education}

Human are the active determining agents. They have power and capacity to change and develop their natural environment. Thus, human's attitudes towards environment are vital. Since human behavior and activities are significant in determining the quality of the environment, educate people to care environment is essential [4]. Sustainability needs human consciousness at individual as well as society levels [12, p. 7]. Thus, education is a path towards human consciousness on (environmental) sustainability.

Environmental education drives people perceptions on environment as well as environmental treatment and management. Environmental education is a process and tool for empowering participation and learning of people at all ages by using two way communication paradigm instead of information flowing from teachers to students [13, p. 318]. The all ages learners' participation in all types of environmental education, from formal to less formal marks the paradigm changes in environmental education [13, p. 318]. Environmental education should provide understanding on natural environment, how it works and human's roles in environmental sustainability and conservation [3, p. 5]. Environmentally fit living for all global community, society and development as well as environmental friendly policy should be highlighted in environmental education program (Borger, 1990, p. 3, cited in Young, 2009, p. 5). Environmental education should specify learning about, for and in environment by understanding rich dynamics of the Earth's natural systems, human economical and social dependency on nature, environmental issues, negative and positive consequences of human-nature interaction (Ontario Ministry of Education, 2007, p. 6, cited in Young, 2009, p. 27). Environmentally-literated learners know society issues and understand their positions in a meaningful context $[3$, p. 27].

Environmental education operates by starting changing human thinking and awareness on nature. It benefits in many aspects of human live, even more beyond the advantages for environment. Promoting moral environmental attitudes, civil action as well as individual and society civil ability are several benefits of environmental education [14]. Environmental education 
also enhances learners' critical thinking, leadership competence, problem solving, academic involvement and healthful lifestyle [15], [16]. Effective environmental education allows the learners' to get knowledge, mindset, skills and practices for participating in local, national and global community, loving each other and all the living species on earth through modeling and responsible action [3, p. 26].

The nature of environmental education pedagogy is grounded on some tenets. Many scholars devoted their thinking exploring several the environmental education principles. Those are covering the need of a nation to improve its' human resource quality to manage abundant natural resources $[17$, p. 2], changing human mental and consciousness $[18$, p. 2$]$, implementing moral and ethical values in interacting with nature/environmental ethics [4], [19, pp. 14-15], dynamically and creatively engaging in searching for environmental issues solutions (http://unesco.unesco.org/images/0010/001056/105607e.p df,cited in Riordan \& Klein, 2010, p. 2), loving nature and his/her own self [4, p. 3914].

Environmental education can take various forms. Environmental knowledge, skills and understanding can be delivered through formal education type, which support the traditional teaching-learning system to less formal delivery, through environmental public services [21, p. 387]. Besides formalizing environment studies, environmental content can be infused into existing main curriculum and building partnership with public agencies are some approaches to environmental education, Education, information and awareness, chapter fifteen [13, p. 319] recommends several approaches to environmental education, including through students' self development program (routine activity, spontaneous action, modeling, conditioning), courses and school culture. Relevant to previous approaches, Saryanto [22] suggests several approaches for environmental education: school curriculum development, direct observation and practice and healthy school development programs.

\section{Young Generation Participation in Environmental Sustainability}

Young generation is the hope of nations. They are the potential leaders, policy makers as well as future developers. They are the inhabitants of the earth now and in the future as well as environmental determiners in their eras. Thus, preparing them for environmental future is vital. Educating children the environmental sustainability is a persistent way to solve environmental pollution (Kang, 1999, cited in Education, information and awareness. Chapter fifteen, n.d., p. 319). As the future earth inhabitants, children have rights to understand their environmental condition and participate in building their future environment. Children have right to enjoy healthy environment which support their physical, social and mental development $[9$, p. 4]. Introducing environmentfriendly activities, inclusiveness and participation in protecting environment are several instances of children's visible participation [9, p. 15]. Experiential learning, such as gardening, hand-on practices, learning while doing, group learning and decision making learning are several approaches to introduce environmental literacy to young generation [9, p. 15]. Education will allow the children to participate in society and understand their potential $[9, \mathrm{p}$. 4]. Moreover, the sustainable issues of environment require natural preservation commitment of young generation grown from engagement, critical thinking as well as study [23]. How environmental understanding and knowledge is introduced to children needs various approaches adapted to children's condition. At the elementary level, for instance, environmental education can be delivered through games, audiovisual tools and natural system learning, while at secondary level, it can be infused to certain courses, such as physics, geography, biology or chemistry [13, p. 391].

\section{Green School and Adiwiyata Program}

School can be a significant place for students to start knowing their environment. School is a place for students to obtain learning experiences and preparing students' future [24, p. 3]. Currently, green school programs are recent trends in environmentally educate students and reduce environmental damage. Green school notion is used interchangeable with some other concepts: ecoschool, green school construction, green curriculum and green environment [25, p. 4]. One of green aspects in green school is green construction. Green building is expected to reduce environmental damage and sustain healthy environment [25, p. 4], [26, p. 778]. Green school construction is indicated by adequate natural light, appropriate ventilation and air quality inside, efficientrenewable energy, safe construction material $[9$, p. 10]. Green learning environment allows the students to learn non-formally from the environment as the basis of lifelong learning and understanding human-influenced protected nature [27, pp. 4-5]. The green schools grow learners' green habit in a designed environmental modeling the taught sustainable principle [9, p. 10].

Green schools serve various environmental educational purposes. Green school prepare green leaders [28, p. 1], [29]. Green schools educate children to develop sensitivity for adaptation and being capable living in nature and increased spiritual and emotional consciousness $[29$, p. 5]. Green schools lead to creative thinking, empowered feeling, adaptation, critical thinking, awareness and collaboration [29, p. 8], learning high performance, increase learning environmental quality and cost effectiveness [30]. Green schools development ground on environmental protection and sustainability: nature preservation, operating cost efficiency, health improvement, increase learning environmental quality, learning chances-built environmental integration [30]. Steps in designing green schools involve collaboration of physical environment and human resource functioning design. ZAS Architects Inc. \& Halsall Associates [30] list some green school initiating stages: building green teams, setting green objectives, budgeting, redefining goals, support gain, green site location, green approach, green design, training, green school operation and continuous improvement. Money saving through conservation, students and staff positive behavior, reduce-reuse-recycle, site greening and increased learning chances are some green school approaches [30]. 
Environmental education for young generation also becomes Indonesian government and society concern. Through Adiwiyata program, The Indonesian Ministry of Environment collaborates with The Indonesian Ministry of Education agree to establish and support environmental-friendly schools which teach learners to conserve and sustain environment for today and future generations [31, p. 2]. Specifically, Adiwiyata aims to increase school community's responsible behavior in environmental conservation and sustainable development [31, p. 2], environmental care and awareness to create ideal learning environment [32, pp. 5-6]. Adiwiyata is sustained by three main principles: participation (of the whole community members) and sustainability (of planned continuous programs/activities) [32, p. 15], [33, p. 9]. Adiwiyata includes several components: environmental policy, green curriculum, participative programs, environmentally-friendly facilities and environment-based school culture [32, pp. 15-16]. Adiwiyata is implemented in many activities, such as Gerebek Sampah, Sampah Balad Kuring, fishpond, green house and bank sampah [34], Green House and Rumah Kompos [35], environmental-friendly waste management and Green House [35], composting and waste-creative handy craft [36].

\section{METHOD}

The research is a qualitative study resulted from our community service programs at MI Walisongo, Desa Sawohan, Sidoarjo in 2018 and 2019. A qualitative inquiry grounds on experience world [37]. The community service program in 2018 is undertaking a particular topic related to the increasing environmental knowledge and awareness of young generation through green school-trees planting programs. Relevant to the previous topic, the community service program in 2019 , is specified into environmental character building through eco-school branding and peer-team working. The intervening program aims to introduce environmental education through green school program, focused on greening school ground and raising students' green awareness (at the first year, 2018) and building green school board and continuing the environmental character building (at the second year, 2019).

MI Walisongo Desa Sawohan is the targeted school as it has several alarming school environmental issues. The first issue is barren school yard. There are only a few big trees. Thus, the school area is very dry. The situation is worsened by the dusty school yard. The second issue is the aging school board which looks old and deteriorates school environment. Learning may not be comfortable in dry and hot school environment. The third issue is lack of local as well as central government concern on environmental education, especially for elementary rural school, such as for MI Walisongo Desa Sawohan. Thus, the community service team aims to encourage and empower school community to start caring their greenness school environment.

The program specified participants are students at 5 and 6 grades. They are purposively selected as they may contribute physically, emotionally and cognitively to
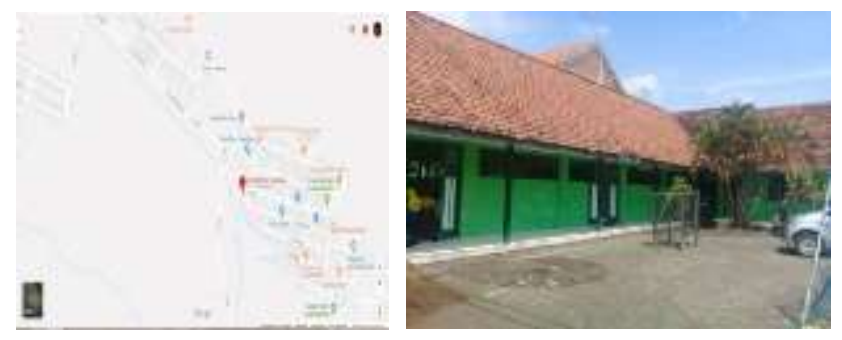

Figure 1. Geographical location and physical condition of $M I$ Walisongo's schoolyard

plant some trees at their school yard. Children at their 810 ages are capable of doing local action research, for instance changing parts of school environment, building birdhouses and community project, including listening to community discussion, helping to build water system by carrying some pipes [9, p. 12].

The data are taken from participant direct observation. The researchers are the community service team who play a role of intervening environmental education: planning, delivering learning material and collaboratively planting trees as well as building school green name board. A qualitative research involves attributes of naturalistic and interpretative I which the researchers examine certain event in real context and define the explored phenomena meaning [38]. The collected data are screened and organized into several emergent themes, interpreted and linked with existing studies. Empirical evidence is collected in qualitative research, and it is followed by low or high data inference [39, p. 456].

\section{RESUlTS AND DisCUSSION}

The study indicates that introducing environmental literacy in MI Walisongo, Desa Sawohan process towards green school involves several environmental education processes. Those are participative learning, character building, modeling, learning through games, green ground construction and peer team learning.

\section{A. Participative Learning}

Engaging MI Walisongo students in greening their school is one of several goals of MI green school program. Through participative learning by letting and supporting the students to plant trees together and collaboratively with their friends and the community service team, student's environmental care, awareness and responsibility are grown.

The students are divided into several small planting groups. Each group is assigned to plant one tree (sawo kecik) in collaboration with the community service team members. All the students are working hard and enjoy working together. Some of them are selfieng while working, taking some pictures with their friends as well as with the team members (as represented in figure 2). Democratic and close interaction emerges during working together to reach shared goals. A participative education allows congenial interaction between teachers and students [40]. Furthermore, children participative learning is relevant to some principles of how children can effectively learn: the principles of active engagement to 
construct their knowledge, social participation and participation in meaningful activities [41, pp. 1-11].
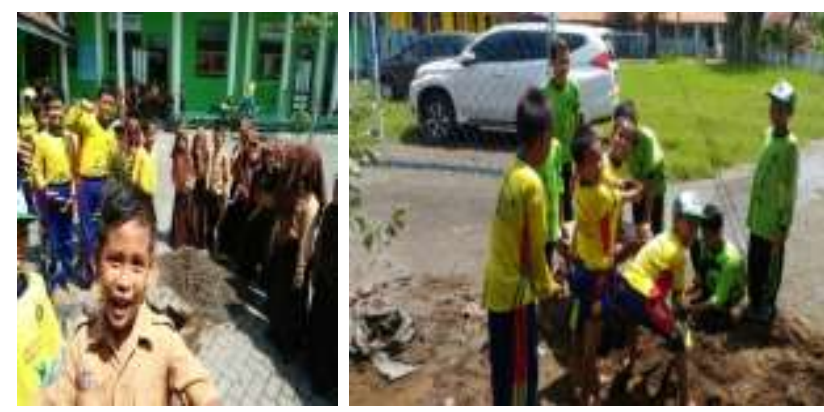

Figure 2. Some MI Walisongo's students are collaboratively planting trees in groups, while playing and enjoying the activity

This participative learning provides real planting experiences. It is expected that by being involved and experiencing real work, the students will understand the meaning of working hard in creating green environment. A participative learning highlights the learners' active involvement in learning process $[42$, p. 2]. This experience may grow senses of environmental care, belonging, awareness and protection commitment. The participative learning may result in students' increased motivation since they can feel their learning process [43]. Moreover, MI Walisongo students' planting experiences gives them authentic environmental learning. Active engagement in planting trees allows the students to construct their knowledge through experience [44]. To reach children's fullest potential, children should not only learn to know, but also learn to be, learn to live together and learn to do [24].

\section{B. Modelling}

In developing MI Walisongo's green school, the community service team develops modeling learning. They are delivering information on the need to preserve school natural environment through ceramah (Islamic lecture) and are followed by demonstrating ways to plant some trees. This demonstration indicates modeling provision. The basic tenet of this modeling is the observational learning. It is expected that after observing the community service team's environmental behavior, the students are imitating the favoured and expected behaviour in their every day life.

In this situation, the community service team plays modeling teachers. They are not only asking the students to green their school, but also showing how to green their school playing ground to allow the students learn through observation. Observational learning occurs only when there is a demonstrated desired behavior [45, p. 7]. At the beginning, the team initiative the works to show what to do and subsequently the students are helping and working together. Observational learning is indicated by learning sequence of engaging, observing, reproducing and reinforcing (Bandura, 1986, cited in Morse, 2017, p. 6). The social learning theory suggests that an individual's behavior is learnt, through model's influence [46, p. 5], [47, p. 9], modeling process and individual's cognition [48, p. 191] and individual's behavior can be changed as the result of observational process $[48$, p. 192]. The role of community and MI Walisongo teachers are significant in facilitating the observational learning. Teachers are affected figures in building and maintaining students' positive attitudes towards their learning [49, p. 145]. Moreover, liked teachers tend to impact long-lastingly and encourage their students to reach success $[50, \mathrm{p} .9]$ and powerful change agents [51, p. 461].

\section{Character Building}

Character education is the soul of environmental education in MI Walisongo. It is delivered by some ustadz (Islamic teachers/educational figures) from community service team. It is provided in forms of Islamic material content, combined with Islamic stories on Nabi, Rosul and their closest friends, as some exemplary figures and society daily life humour. The represented figures are ranging from Arabic to local figures, including Robitul Adawiyah, Sunan Bonang and Sunan Kalijogo and Imam Gozali. The Islamic material delivery (ceramah) is inserted with some yel yel which the students should pronounce loudly together and in high enthusiasm. The environmental care character is one of targeted characters which should be developed in Indonesia through balanced ethic, literacy, aesthetic and kinesthetic, grounded on Kemendikbud PPK (character strengthening program) [52, p. 88], [53], [54, p. 3]. Moreover, character education should be given at the youngest age of children [54, p. 3] to set strong foundation for subsequent years [55, p. 27] and continually instilled [55, p. 23] as it is not a fast product (Character Education Partnership, 2010, cited in Pala, 2011, p. 25). Furthermore, collaborative works among parents, teachers and schools are required in character education [55, p. 28]. Family, teachers and society are the interveners in creating children's main character through habituation [56, p. 11].

This verbal character education is the first education activity and opens the gate towards other activities: collaborative planting, building school green board and learning through games. The team is aware that environmental care behavior is grounded on students' character-rooted behavior. Children's environmental care and awareness should be implanted to and grown from their heart. Thus, educating children's morality is the priority action in MI Walisongo green school. Environmental love should not come from outside, but inside driving forces, virtues and moral value [4]. Good characters are encapsulating three elements: moral knowledge, moral senses and moral action (Lickona in Setiawan, 2013, cited in Pane \& Patriana, 2016, p. 247). Environmental character influences students' thinking, affection, psychomotoric and social functions in humanenvironment relationship [17, p. 3]. The environmental education benefits are not only for environmental damage reduction, but also for students' learning process. Lifelong learning, leadership, increased motivation career planning, responsibility and respect attitudes are several value added in environmental education [16, p. 1].

This verbal character education is the first education activity and opens the gate towards other activities: collaborative planting, building school green board and learning through games. The team is aware that 
environmental care behavior is grounded on students' character-rooted behavior. Children's environmental care and awareness should be implanted to and grown from their heart. Thus, educating children's morality is the priority action in MI Walisongo green school. Environmental love should not come from outside, but inside driving forces, virtues and moral value [4]. Good characters are encapsulating three elements: moral knowledge, moral senses and moral action (Lickona in Setiawan, 2013, cited in Pane \& Patriana, 2016, p. 247). Environmental character influences students' thinking, affection, psychomotoric and social functions in humanenvironment relationship [17, p. 3]. The environmental education benefits are not only for environmental damage reduction, but also for students' learning process. Lifelong learning, leadership, increased motivation career planning, responsibility and respect attitudes are several value added in environmental education $[16$, p. 1].

\section{Green Site Construction}

Besides environmental character education provision, school green site/space is built together. MI Walisongo's schoolyard is greening by sawo kecik trees and building green school name board (as represented in figure 3 ). The schoolyard greening aims to provide healthy and safe environment for children to play and learn. Dusty playing ground may impact on students' health as well as uncomfortable learning place.

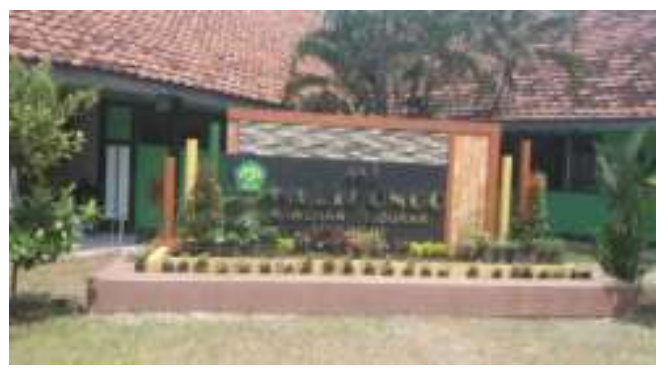

Figure 3. A green school name board, one of some built green school spaces at MI Walisongo

Fresh air school environment is expected to increase students' motivation to learn inside and outside classrooms, promote students' wellbeing and contribute to environmental freshness of rural area (of school surrounding environment). The green school name board increases the greenness of MI Walisongo while promoting the school existence. Some sitting spaces are built around the name board to allow students learn outside classroom, relax and play with their peers in a healthy environment. Green school building, spaces and grounds promote children's health and protect them from illnesses. Learning at healthy and safe environment are fundamental rights for every student [24, pp. 15-16], [58, p. 720], [59, p. 13], [60, p. 15]. Building school green areas provides enormous benefits for children. Green school reduces in and out door air pollution which impacts on school air quality and students' immunity [25, p. 4]. Many studies find that green school relates to students' health [61]-[63]. Green environment invites school community to do various outdoor activities as well as serve multi-functions of stress-reliever, recreational space and aesthetic function [62]. Green school garden maintain school ecological sustainability [62, p. 3].

It is expected that MI Walisongo's greenness will result in students' increased learning motivation and fun in learning. Some studies recommend positive impacts of green school for students' learning. Green school adds new nature experiences, knowledge, learning passion, and citizens' conscientiousness [64], increases students contact with nature and educational outdoor activities [65], opens access to environmental education fieldwork [66] and improves cognition development [61].

\section{E. Environmental Education Games}

The green education in MI Walisongo is enhanced by group-designed creative game. The community service team together creates environmental education game and game activities (as represented in figure 4). Games, audiovisual kits and natural system learning are usually used to introduce environmental literacy for children at primary and pre-school levels [13, p. 319].
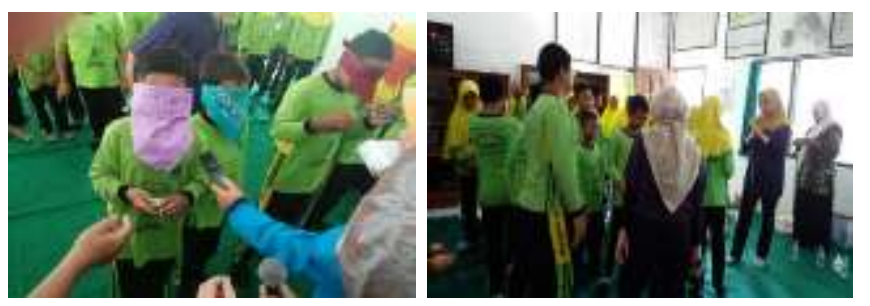

Figure 4. Environmental game activities

The aims of the designed game are increasing students' knowledge on local fruits, which are usually planted around their areas, and local herbs, enhancing students' sensory capacity to identify the fruits and herbs, promoting cooperation with friends in fruits/herbs identification. The primary objective is encouraging the students to know and love their local environment products. Enormous researches on educational games highlight the benefit for children. Games are engaging technique to make children feel fun [67]-[69] and feel motivated [70, p. 114]. Game is an effective ice breaker, tool for pointing out highlighted material, emerging creative thinking, presenting different learning approach, promoting problem solving, engaging students, facilitating peer learning and aiding concentration [71, $\mathrm{p}$. 3].

The game is arranged into several three main sessions. In the first session, the players are asked to identify fruits/herbs smell using their noses. In the second session, the players identify the fruits/herbs texture using their hand and in the last session, they are asked to guess and point fruits/herbs based on the given characteristics/clues. At the end of the game, the winner groups are appreciated with some gifts and the other groups are given some snacks and chocolates to value their engagement. The game activity is a bridging game to planting trees activity. Environmental games can be used to increase children's ecological sensitivity [70, p. 114]. The other benefits are games are encouraging children players to learn how to learn, identify one's weakness and strength, solve particular challenges, learning transfer from games to real context and emerge intrinsic motivation [68, p. 7]. 
The $1^{\text {st }}$ International Conference on Global Development - ICODEV

November $19^{\text {th }}, 2019$, Rectorate Building, ITS Campus, Sukolilo, Surabaya, Indonesia

\section{F. Peer Learning and Team working}

The other learning approach to support and sustain MI Walisongo's green school is peer learning and team working. In several activities, such as group game and planting trees together, the students are asked to collaborate, work together with their peers. In games, they are collaboratively tackling the given challenges. In planting trees, they are doing some shared works, including fertilizing, digging soils, planting trees, watering trees. Peer relationship is the foundation of effective collaborative works, as indicated by shared goals, roles and responsibilities understanding, tolerance, volunteering and respect $[72$, p. 697] and synergism [73, p. 641].

This enhanced group activity aims to teach the students to protect environment together. Environmental sustainability cannot be executed independently as a separate act. Instead, it needs collaborative actions from all society elements. This principle should be educated to young generation at their primary level. Collaboration is the backbone of sustainability act. Environmental issues are resulted from the competing interest of myriad stakeholders and collaboration among those stakeholders is required to create new social values promoting sustainability $[74, \quad$ p. 22]. Collaboration, joint development and partnership are requirement to successful sustainability [75, p. 1], [76]. Sustainability failure is caused by lack of collaborative actions [77].

\section{CONCLUSION}

Environmental education for young generation is one of visible problem solving for reducing environmental damage. School is a central learning venue providing environmental experiences, knowledge and feeling. Environmental education through green school is one of many environmental cares which can provide basis for students' environmental actions. MI Walisongo's green school development indicates that environmental education requires combination of various learning approaches: building character, participative learning, green space building, modeling, peer and team working as well as educational gaming. The study also finds that building green area in school only, is not sufficient. It should be supplemented with raising students' awareness cognitively, emotionally and practically.

\section{REFERENCES}

[1] J. T. Liberty, B. O. Ugwushiwu, G. I. Bassey, and V. N. Eke, "Effects of Natural Resources Utilization on the Ecosystem and Its Remedies in Nigeria," IJSER, vol. 4, no. 8, pp. 2115-2122, 2013.

[2] "What is the environment in the context of health?"

[3] J. L. M. Young, "All Education is Environmental Education," Queen's University Kingston, Ontario, Canada, 2009.

[4] C. H. P. Moreno, I. D. M. Acero, and N. H. P. Rodriguez, "Education for environment care: contribution through human ecology," Procedia Social and Behavioral Sciences, vol. 15, pp. 3912-3915, 2011

[5] C. Vlek and L. Steg, "Human Behavior and Environmental Sustainability: Problems, Driving Forces, and Research Topics," Journal of Social Issues, vol. 63, no. 1, pp. 1-19, 2007.

[6] H.-H. Weng, J.-S. Chen, and P.-C. Chen, "Effects of Green Innovation on Environmental and Corporate Performance: A
Stakeholder Perspective," Sustainability, vol. 7, pp. 4997-5026, 2015.

[7] G. H. Brundtland et al., "Environment and Development Challenges: The Imperative to Act," The Asahi Glass Foundation, Tokyo, Japan.

[8] D. Baus, "Overpopulation and the Impact on the Environment," The City University of New York, 2017.

[9] UNICEF, "Climate Change and Environmental Education. A companion to the Child Friendly Schools Manual," Child Friendly Schools-Unicef.

[10] "Natural Resources and Pro-Poor Growth. The economics and politics," OECD, France, 2008.

[11] The Irish Council for Bioethics, "Environmental Ethics: Whose Planet is it Anyway?," The Irish Council for Bioethics, Dublin.

[12] I. Šlaus and G. Jacobs, "Human Capital and Sustainability," Sustainability, vol. 2, no. 1, pp. 1-61, 2011.

[13] "Education, information and awareness. Chapter fifteen."

[14] L. Chawla and D. F. Cushing, "Education for strategic environmental behaviour.," Environment Education Research, vol. 13, no. 4, pp. 437-452, 2007.

[15] M. Archie, Advancing education through environmental literacy. Alexandria, VA: Association for Supervision and Curriculum Development, 2003.

[16] The North American Association for Environmental Education, The National Environmental, and Education \& Training Foundation, "Using environment-based education to Advance Learning Skills and Character Development," The North American Association for Environmental Education and The National Environmental Education \& Training Foundation, Washington, D.C, A Report, Annotated Bibliography, and Research Guide, 2011.

[17] E. F. Rini, "Implementasi pendidikan karakter peduli lingkungan melalui pembelajaran pendidikan lingkungan hidup (PLH) di Sekolah Dasar Muhammadiyah Alam Surya Mentari Tahun ajaran 2016/2017," Universitas Muhammadiyah Surakarta, 2017.

[18] S. Hayati, "Pendidikan lingkungan hidup (PLH) dalam membentuk perilaku lingkungan bertanggung jawab," pp. 1-11.

[19] A. D. Wulandari, "Perilaku peduli lingkungan masyarakat dalam pengelolaan Desa Wisata Kandri Kecamatan Gunungpati Kota Semarang," Pendidikan Geografi, Fakultas Ilmu Sosial, Universitas Negeri Semarang, 2017.

[20] M. Riordan and E. J. Klein, "Environmental Education in Action: How Expeditionary Learning Schools Support Classroom Teachers in Tackling Issues of Sustainability," Teacher Education Quarterly, 2010.

[21] W. Hutcheson, P. Hoagland, and D. Jin, "Valuing environmental education as a cultural ecosystem service at Hudson River Park," Ecosystem Services, vol. 31, pp. 387-394, 2018.

[22] Saryanto, "Pelaksanaan pendidikan cinta lingkungan di Sekolah Dasar Negeri Piyaman I Wonosari Gunungkidul Yogyakarta," Program Studi Pendidikan Guru Sekolah Dasar, Jurusan Pendidikan Pra Sekolah dan Sekolah Dasar. Fakultas Ilmu Pendidikan, Universitas Negeri Yogyakarta, 2014.

[23] N. (Eds.) Noddings, Educating Citizens for Global Awareness. Columbia University: Teachers College Press, 2005.

[24] UNICEF, "Manual. Child Friendly Schools," United Nations Children's Fund, New York, 2009.

[25] A. Iwan and N. Rao, "The Green School Concept: Perspectives of Stakeholders from Award-Winning Green Preschools in Bali, Berkeley, and Hong Kong," Journal of Sustainability Education, no. 16, 2017.

[26] A. Ragheb, H. El-Shimy, and G. Ragheb, "Green architecture: A concept of sustainability," Procedia - Social and Behavioral Sciences, vol. 216, pp. 778 - 787, 2016.

[27] N. (Ed) Györek, "Green Learning Environments: The Benefits of (Learning in) Nature for Children with Special Educational Needs," Institute for Forest Pedagogics, Kamnik, ERASMUS2016-1-BE02-KA201-017373, 2018.

[28] K. Druhan, "Green School Bali. Annual Report 2017/18. A Community of Learners, Making OurWorld Sustainable," Green School Bali, Annual Report.

[29] L. Medema, "Green school prospectus. A community of learners making our world sustainable," Green School Bali.

[30] ZAS Architects Inc and Halsall Associates, "Green Schools. A Practical Resource for Planning and Building Green Schools in Ontario. Resource Guide." 
[31] A. Nur, Jamaluddin, and R. Niswaty, "Efektifitas pelaksanaan program Adiwiyata di SDN Mangkura 1 Makassar."

[32] Asrianti, "Hubungan antara program Adiwiyata dengan sikap peduli lingkungan siswa di SMP Negeri 2 Barombong Kabupaten Gowa," Fakultas Tarbiyah dan Keguruan UIN Alauddin Makassar, 2016.

[33] "Program Adiwiyata," Universitas Muhammadiyah Malang.

[34] R. B. Ramdhani, "Implementasi program Adiwiyata dalam pengelolaan lingkungan sekolah di SMPN 3 Sukabumi," International Journal Pedagogy of Social Studies, vol. 1, no. 2, 2016.

[35] A. S. Fridantara, "Implementasi program Adiwiyata di SMA Negeri 2 Klaten," Program Studi Manajemen Pendidikan Jurusan Administrasi Pendidikan Fakultas Ilmu Pendidikan Universitas Negeri Yogyakarta, 2015.

[36] M. D. F. Bahrudin, "Pelaksanaan program Adiwiyata dalam mendukung pembentukan karakter peduli lingkungan di SMA Negeri 4 Pandeglang," Jurnal Pendidikan Geografi, vol. 17, no. 1, pp. 25-37, 2017.

[37] S. Ospina, "Qualitative Research," in Encyclopedia of Leadership, G. Goethals, G. Sorenson, J. MacGregor (Eds.)., London: SAGE Publications, 2004.

[38] N. Denzin and Y. Lincoln, Handbook of Qualitative Research. London: Sage Publications, Inc., 2000.

[39] N. N. Feza, "Chapter 25. Qualitative Data analysis," 2015, pp. 456-474.

[40] K. A. Romanova and M. S. Lyshenko, "A Participative Approach to Teaching and Learning in Higher School," World Applied Sciences Journal (Special Issue of Pedagogy and Psychology), vol. 20, pp. 84-89, 2012.

[41] S. Vosniadou, "How children learn," International Academy of Education, France, 2001.

[42] K. Horgan and D. O'Rourke, "Development Education \& Participative Learning Methodologies (PLM) at Third Level," pp. $1-15$.

[43] A. Kucharčíková and E. Tokarčiková, "Use of participatory methods in teaching at the university," www.tojsat.net, vol. 6, no. 1 , pp. 82-90, 2016

[44] A. D. Omollo, B. Nyakrura, and Y. S. Mbalamula, "Application of Participatory Teaching and Learning Approach in Teacher Training Colleges in Tanzania," Journal of Scientific Research \& Reports, vol. 16, no. 6, pp. 1-10, 2017.

[45] B. A. B. Morse, "The role of observational learning in developing ecotourists' environmentally responsible behavioural intentions," The University of Michigan, 2017.

[46] A. Bandura, Social Learning Theory. New York: General Learning Press, 1971.

[47] M. Zhou and D. Brown, Educational Learning Theories: 2nd E dition. Education Open T extbooks. 1.

[48] M. J. Fryling, C. Johnston, and L. J. Hayes, "Understanding Observational Learning: An Interbehavioral Approach," The Analysis of Verbal Behavior, vol. 27, pp. 191-203, 2011.

[49] D. M. McInerney and V. McInerney, Educational Psychology. Constructing learning, 3rd Ed. NSW: Pearson Education Australia Pty Limited, 2002.

[50] S. Bashir, M. Bajwa, and S. Rana, "Teacher as a role model and its impact on the life of female students," International Journal of Research - Granthaalayah, vol. 1, no. 1, pp. 9-20, 2014

[51] M. Sellars, "Teachers and change: The role of reflective practice," Procedia - Social and Behavioral Sciences, vol. 55, pp. 461-469, 2012.

[52] R. Adawiah, "Instilling the Environmental Care Characters to the Elementary Schools Located on the River Banks," Journal of Wetlands Environmental Management, vol. 6, no. 1, pp. 8492, 2018.

[53] Kementerian Pendidikan dan Kebudayaan and Republik Indonesia, "Konsep Dasar Penguatan Pendidikan Karakter. 'Senang belajar di rumah kedua," Kementerian Pendidikan dan Kebudayaan Republik Indonesia.

[54] M. R. Trahati, "Implementasi pendidikan karakter peduli lingkungan di Sekolah Dasar Negeri Tritih Wetan 05 Jeruklegi Cilacap," Jurnal Pendidikan Guru Sekolah Dasar, vol. 12, no. IV, pp. 1-10, 2015.

[55] A. Pala, "The need for character education," International Journal of Social Sciences and Humanity Studies, vol. 3, no. 2, pp. 23-32, 2011

[56] E. Sulistyowati, Implementasi Kurikulum Pendidikan Karakter. Yogy akarta: Citra Aji Parama, 2012.
[57] M. M. Pane and R. Patriana, "The Significance of environmental contents in character education for quality of life," Procedia-Social and Behavioural Sciences, vol. 222, pp. 244-252, 2016.

[58] T. Mwoma, N. Begi, and C. Murungi, "Safety and security in preschools: A challenge in informal settlements," Issues in Educational Research, vol. 28, no. 3, pp. 720-736, 2018.

[59] NCCA, "Guidelines for Wellbeing in Junior Cycle 2017," National Council for Curriculum and Assessment, 2017.

[60] B. Rasmusson, L. Andersson, A. Wångdahl Flinck, U. Leo, and P. Wickenberg, "Realising Child Rights in Education Experiences and Reflections from the International Training Programme on Child Rights, Classroom and School Management," Lund University, Sweden, 2016.

[61] P. Dadvand et al., "Green spaces and cognitive development in primary school children," PNAS, vol. 112 , no. 26 , pp. $7937-$ 7942, 2015.

[62] R. Figueroa, "About School Gardens and Other Campus Green Spaces."

[63] R. Nauert, "Green Space at School Improves Child Health," Psychcentral, 2018.

[64] BCWH, "Benefits of Green Spaces in Schools," 2019.

[65] A. Akoumianaki-Loannidou, A. T. Paraskevopoulou, and V. Tachou, "School grounds as a resource of green space to increase child-plant contact," Urban forestry \& urban greening, vol. 20 , no. 1 , pp. 375-386, 2016.

[66] M. Wolsink, "Environmental education excursions and proximity to urban green space- - Densification in a 'compact city",", Environmental Education Research, vol. 22, no. 7, pp. 1049-1071, 2016.

[67] D. Kirkland and F. O'Riordan, "Games as an Engaging Teaching and Learning Technique: Learning or playing?"

[68] D. Moursund, "Introduction to Using Games in Education: A Guidefor Teachers and Parents," University of Oregon.

[69] OPATS, "Environmental Activities for Youth Clubs and Camps," Office of Overseas Programming and Training Support (OPATS), Washington, DC, Publication No. M0126, 2017.

[70] M. Branco et al., "Games in the environmental context and their strategic use for environmental education," Braz. J. Biol, vol. 75, no. 2, pp. S114-S121, 2015.

[71] S. Boyle, "Teaching Toolkit. An Introduction to Games based learning," UCD Dublin.

[72] W. Umiker, "Professional perspectives. Peer relationships: Key to successful team," Laboratory Medicine, vol. 28, no. 11, pp. 696-697, 1997.

[73] P. Tarricone and J. Luca, "Successful teamwork: A case study," HERDSA, pp. 640-646, 2002.

[74] C. L. Hartman, P. S. Hofman, and E. R. Stafford, "Environmental collaboration. Potential and Limits," in Partnership and Leadership, The Netherlands: Kluwer Academic Publishers, 2002, pp. 21-40.

[75] S. G. Azevedo, M. E. Silva, J. C. O. Matias, and G. P. Dias, "The Influence of Collaboration Initiatives on the Sustainability of the Cashew Supply Chain," Sustainability, vol. 10, no. 2075, pp. 1-29, 2018.

[76] T. Bjärstig, "Does Collaboration Lead to Sustainability? A Study of Public-Private Partnerships in the Swedish Mountains," Sustainability, vol. 19, no. 1685, pp. 1-22, 2017.

[77] M. Howes et al., "Environmental Sustainability: A Case of Policy Implementation Failure?,” Sustainability, vol. 9, no. 165, pp. 1-17, 2017. 